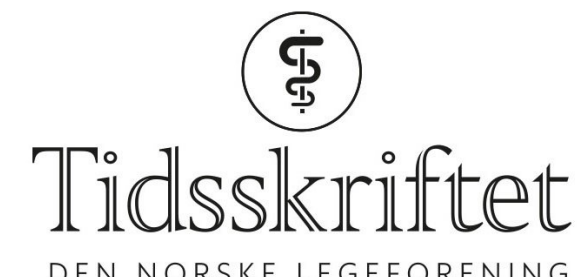

DEN NORSKE LEGEFORENING

\title{
Mobbing blant leger i Norge
}

LEGELIVET

\section{JUDITH ROSTA}

E-post: judith.rosta@legeforeningen.no

Judith Rosta (f. 1968) er seniorforsker ved LEFO - Legeforskningsinstituttet.

Forekomsten av opplevd mobbing fra kolleger eller overordnede har holdt seg stabil på et relativt høyt nivå i perioden 1993-2014/15.

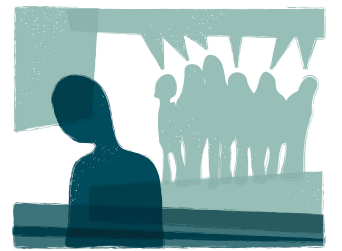

Illustrasjonsfoto: borisz/iStock

Forekomsten av mobbing på arbeidsplassen og negative effekter av mobbing på individ- og organisasjonsnivå er godt dokumentert for flere yrkesgrupper i Norge $(1,2)$, men det er få studier som viser data spesielt for legegrupper (3).

I en fersk studie, basert på Legeforskningsinstituttets legepanel, har vi sett på utviklingen av opplevd mobbing på arbeidsplassen for leger i ulike jobbkategorier og for sykehusleger i ulike medisinske disipliner i 1993, 2004 og 2014-15 (4).

Studien viste at andelen leger som rapporterte at de hadde opplevd mobbing fra kolleger eller overordnede minst et par ganger i måneden i løpet av det siste året, har holdt seg stabil på mellom 6-7\% i den undersøkte perioden. Disse tallene inkluderer ikke eventuell mobbing fra pasienter og pårørende. På alle tre måletidspunktene var det flere overleger og legeledere i sykehus som rapporterte om mobbing på jobb, enn leger i spesialisering, fastleger og privatpraktiserende leger. Forekomsten i ulike medisinske disipliner innen sykehus lå høyest for leger i kirurgi og i laboratoriefag i 1993 og 2004, og for leger i kirurgi og i psykiatri i 2014-15.

Analysen viste også at opplevelsen av mobbing var assosiert med å være kvinnelige leger, med å ha høyere skår på personlighetstrekket sårbarhet og med lavere grad av jobbtilfredshet og selvrapportert helse, men var ikke assosiert med alder eller $\emptyset \mathrm{kt}$ sykefravær (4). Siden dette var basert på tverrsnittsdata, kan man imidlertid ikke si noe om årsaksforholdene.

Våre funn er i tråd med andre norske studier som tyder på at forekomsten av opplevd mobbing på jobb har vært stabil for den yrkesaktive populasjonen i perioden 1989-2013 (2-3\%), og at arbeidstakere i helse- og sosialsektoren hadde større risiko for å være utsatt for mobbing enn gjennomsnittet (2). 
En stabil og relativt høy forekomst av mobbing på jobb innenfor legegrupper kan tilskrives så vel kulturelle faktorer som tradisjonelle hierarkiske strukturer og undervisningsmetoder i det medisinske yrket (5). I tillegg peker man i undersøkelser på høye psykososiale risikofaktorer i legeyrket, inkludert lange arbeidsuker, nattarbeid, hyppige reorganiseringer på arbeidsplassen, høy arbeidsinnsats og stress (2). Det kan øke konfliktnivået, noe som igjen er en viktig risikofaktor for utvikling av mobbing (6).

God ledelse, sosial støtte og forbedret psykososialt arbeidsmiljø, kombinert med aktive arbeidsplassintervensjoner, er avgjørende for å hindre mobbing på jobb. Undervisning om dette temaet i medisinstudiet og spesialistutdanningen kan øke bevisstheten om mobbing og være viktig for å forbedre kommunikasjonen og forholdet mellom kolleger. Et godt arbeidsmiljø bidrar positivt, ikke bare til legers egen helse og jobbtilfredshet, men også til bedre behandlingskvalitet og høyere pasientsikkerhet (4-6).

\section{LITTERATUR:}

1. Birkeland Nielsen M, Magerøy N, Gjerstad J et al. Mobbing i arbeidslivet og senere helseplager. Tidsskr Nor Legeforen 2014; doi: 10.4045/tidsskr.13.o88o. [CrossRef]

2. Levekårsundersøkelsen. 2013. Arbeidsmiljø. Oslo: Statistisk Sentralbyrå, 2014. https://www.ssb.no/arbeid-og-lonn/statistikker/arbmiljo/hvert-3-aar/2014-07-03 (28.5.2018).

3. Andersen GR, Aasland OG, Fridner A et al. Harassment among university hospital physicians in four European cities. Results from a cross-sectional study in Norway, Sweden, Iceland and Italy (the HOUPE study). Work 2010; 37: 99-110. [PubMed]

4. Rosta J, Aasland OG. Perceived bullying among Norwegian doctors in 1993, 2004 and 2014-2015: a study based on cross-sectional and repeated surveys. BMJ Open 2018; 8: e018161. [PubMed][CrossRef]

5. Musselman LJ, MacRae HM, Reznick RK et al. 'You learn better under the gun': intimidation and harassment in surgical education. Med Educ 2005; 39: 926 - 34. [PubMed][CrossRef]

6. Hauge LJ, Skogstad A, Einarsen S. Relationships between stressful work environments and bullying: Results of a large representative study. Work Stress 2007; 21: 220 - 42. [CrossRef]

Publisert: 26. juni 2018. Tidsskr Nor Legeforen. DOI:10.4045/tidsskr.18.0350

(C) Tidsskrift for Den norske legeforening 2020. Lastet ned fra tidsskriftet.no 